\title{
Study on the Degradation of Oilfield Wastewater Treatment by Three-Dimensional Electrode
}

\author{
Qian Liu', Han Yang1, Bo Jing2,3, Wenjuan Chen ${ }^{2,3}$, Wu Chen1, Xianqing Yin ${ }^{*}$ \\ ${ }^{1}$ College of Chemical and Environmental Engineering, Yangtze University, Jingzhou, China \\ ${ }^{2}$ State Key Laboratory of Offshore Oil Exploitation, Beijing, China \\ ${ }^{3}$ CNOOC Research Institute, Beijing, China \\ Email: ${ }^{*}$ jzyinxq@126.com
}

How to cite this paper: Liu, Q., Yang, H., Jing, B., Chen, W.J., Chen, W. and Yin, X.Q. (2017) Study on the Degradation of Oilfield Wastewater Treatment by ThreeDimensional Electrode. Open Journal of Yangtze Gas and Oil, 2, 67-81.

https://doi.org/10.4236/ojogas.2017.22005

Received: January 10, 2017

Accepted: April 23, 2017

Published: April 26, 2017

Copyright $\odot 2017$ by authors and Scientific Research Publishing Inc. This work is licensed under the Creative Commons Attribution International License (CC BY 4.0).

http://creativecommons.org/licenses/by/4.0/

\begin{abstract}
The COD value is the main control index of sewage standard. The method of three-dimensional electrocatalytic oxidation is studied for deep treatment of oilfield sewage. The oxidation mechanism and the structure of the three-dimensional electrode reactor are analyzed and optimized. A series of single factor experimental results show that each control parameter has different influences on COD removal rate in the process of oxidative degradation. Based on the experimental study of electrode materials, electrode filled particles, electrolysis current and resident time of sewage, when the system condition are DSA electrode-F plate, the electrode particles of activated carbons:glass beads:quartz sands $=5: 2: 2$, the electrolysis current of $6 \mathrm{~A}$ and the retention time of $50 \mathrm{~min}$, the sewage by oxidized treatment meets the discharge standard of COD $\leq 50 \mathrm{mg} \cdot \mathrm{L}^{-1}$. The SEM result analysis of DSA electrode-F plate before and after using for a period of time shows the electrode material is stable, and no dissolution and corrosion occur. The UV-Vis absorption spectroscopy analysis of water samples in the wavelength range of $200-600 \mathrm{~nm}$ shows pollutants in sewage are degraded into small molecules, and refractory organic pollutants are effectively removed.
\end{abstract}

\section{Keywords}

Three-Dimensional Electrochemical Reactor, Oilfield Sewage, DSA Electrode, SEM

\section{Introduction}

In the process of high efficient oil recovery by polymer injection in oil field, some sewage needs treatment to meet the discharge COD (chemical oxygen de- 
mand) standards. The composition of this oily sewage is complex, and the sewage contains residual agents, residual trace oil, residual polymers and so on [1] from various technical measures. Using conventional sewage treatment technology is difficult to achieve national and local control standards. Advanced oxidation deep treatment technology is an important method to meet the sewage discharge standard, and electrochemical catalytic oxidation [2] [3] [4] is fast and efficient in COD removal, strong in the control process, and easy to use with other unit process. It can deal with both inorganic and organic pollutants without the addition of REDOX agents and secondary pollution, and it is an environmentally friendly green water treatment technology. The basic principle of three-dimensional electrode [5] [6] in COD treatment is electric catalytic REDOX reaction. The particles are respectively brought into positive and negative charges by electrostatic induction under the action of electric field between the main electrodes, then each particle becomes an independent electrode, and electrochemical REDOX reaction takes place at the surface of each particle at the same time to make the organic pollutants degraded. Compared with the conventional twodimensional electrode reactor, the three-dimensional electrode has an increase in the surface area of the working electrode, a decline in the migration distance of the reactants, a high mass transfer and reaction speed, a high current and time-space efficiency, and a great improvement in treatment effect. The authors fabricate a PFR (plug flow reactor) fixed-bed three-dimensional electrode reactor, the study object is import oily sewage from the biochemical unit in an oilfield sewage treatment system. The sewage contains trace oil and some polymer with high salinity; it contains little pollutants for surface water such as ammonia nitrogen. The feasibility of continuous treatment of oilfield sewage by electrochemical oxidation is studied, and the main effect factors such as electrode materials, electrode particles, electrolysis current and resident time of sewage on the COD control treatment of oilfield sewage are systematically studied to determine process control parameters for advanced treatment of oilfield sewage.

\section{Experimental Section}

\subsection{Experimental Instruments and Chemicals}

Dionex-ICS2100 ion chromatograph, Agilent 5975C Chromatography-Mass Spectrometer, DR1010 COD tester (HACH COMPANY, U.S.A.) and HACHCOD preformed tube agent (15 - $\left.150 \mathrm{mg} \cdot \mathrm{L}^{-1}\right)$, Hitachi-SU8010 scanning electron microscope (SEM), WYK-60V DC stabilized power supply, UV-2450 UV-Vis spectrophotometer (Shimadzu), ZD-3A automatic potentiometric tester (Jiangsu Jintan), CH-II mini continuous sewage treatment equipment, Electrochemical homemade PFR reactor. Water quality analysis in accordance with DB21/16272008 "Wastewater Integrated Discharge Standard", SY/T5523-2016 “oilfield water analysis methods".

\subsection{Water Quality Analysis}

The experimental water samples are taken from the outlet of Physicochemical 
treatment process, and the content of $\mathrm{Cl}^{-}$is $5436.34 \mathrm{mg} \cdot \mathrm{L}^{-1}$. The results are shown in Table 1.

\subsection{Experimental Process}

Three-dimensional electrode reactor designed to dual electrodes is mainly made up of electrolyzer, electrodes, filler particles, power, sampling port shown in Figure 1. It is made of Plexiglas into sealed container whose length $\times$ width $\times$ height is $260 \mathrm{~mm} \times 250 \mathrm{~mm} \times 256 \mathrm{~mm}$ and effective treatment volume is $4 \mathrm{~L}$. The reticular titanium whose surface is made into inert electrode material by the different ruthenium and iridium oxides is used as dual electrodes with the specification of $120 \times 120 \mathrm{~mm}$. Rod-like activated carbons (after pretreatment of saturated adsorption) are filled between the positive and negative electrode plates with a certain amount of insulative particles of quartz sand and glass beads [7] [8] as the mass ratio of activated carbon:glass beads:quartz sand $=5: 2: 2$ and the surface/volume ratio of $3 / 10\left(\mathrm{~cm}^{2} \cdot \mathrm{L}^{-1}\right)$. The flowing state of it is similar to that of PFR reactor.

\subsection{Principle and Method of Three-Dimensional Electrode Reaction}

The treatment effect of two-dimensional electrode in a limited time can not meet the requirements, therefore, the problem such as the small surface/volume ratio and the low efficiency needs to be solved. The three-dimensional electrode is directly filled with the particle electrode between the dual electrodes, and each particles become the independent third electrode which greatly increase the reaction area of the reactor, so that the electrochemical reaction spreads from

Table 1. Parameters of oilfield sewage water quality $\left(\mathrm{mg} \cdot \mathrm{L}^{-1}\right)$.

\begin{tabular}{|c|c|c|c|c|c|c|c|c|c|c|}
\hline Parameters & salinity & $\mathrm{CL}^{-1}$ & $\mathrm{COD}_{\mathrm{cr}}$ & polymer & oil & $\mathrm{NH}_{3}-\mathrm{N}$ & chromaticity color & SS & $\mathrm{pH}$ & Conductivity $/ \mu \cdot \mathrm{s} \cdot \mathrm{cm}^{-1}$ \\
\hline Results & 9374.34 & 5436.34 & $230-342$ & 89.5 & 12.2 & 33.65 & 18 & 12 & 7.05 & 16.82 \\
\hline
\end{tabular}

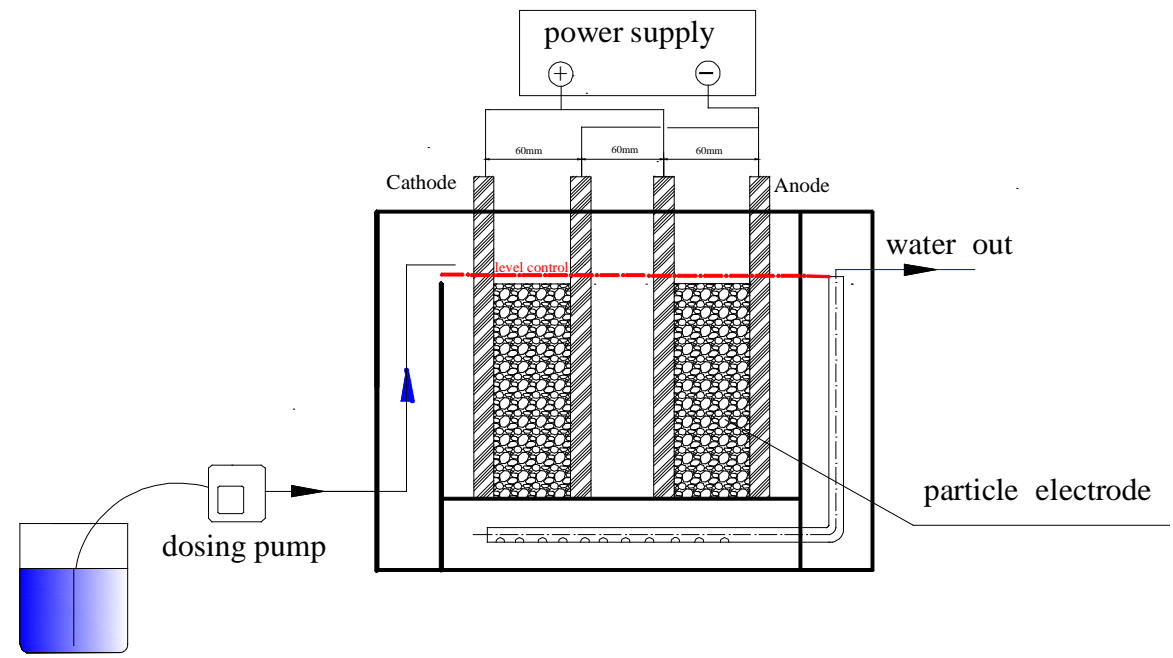

Figure 1. Electrochemical experimental device process. 
the electrode surface to the whole three-dimensional space. It improves mass transfer effect, and further improves the electrochemical reaction efficiency, the structure of the three-dimensional electrode is shown in Figure 2. The reaction mechanism is still the electrochemical degradation reaction [9] [10], active oxides are produced in the reaction process to form a dynamic process of adsorption-electrolysis-desorption. The existence of electrode particles improves specific surface area and adsorption capacity of the electrodes, electrode particles are charged due to induction in the electric field, so both sides of electrode particle present positive and negative poles to form a number of micro-electrolysis cells, then the electrochemical oxidation and reduction reaction occurs. It shortens the mass transfer distance, and improves the current efficiency and time-space efficiency, and rapidly decomposes pollutants in water.

Anodic reaction: $\cdot \mathrm{OH}$ radicals are produced at a suitable anode potential.

$$
\begin{gathered}
\mathrm{H}_{2} \mathrm{O} \rightarrow \cdot \mathrm{OH}+\mathrm{H}^{+}+e \\
2 \mathrm{Cl}^{-} \rightarrow \mathrm{Cl}_{2}+2 e \\
4 \mathrm{OH}^{-} \rightarrow 2 \mathrm{H}_{2} \mathrm{O}+\mathrm{O}_{2}+4 e
\end{gathered}
$$

The precipitated chlorine reacts immediately with the $\mathrm{OH}^{-}$produced on the cathode to form a hypochlorous acid active intermediate.

$$
\mathrm{Cl}^{-}+2 \mathrm{OH}^{-}-2 e \rightarrow \mathrm{ClO}^{-}+\mathrm{H}_{2} \mathrm{O}
$$

$\mathrm{Cl}^{-}$follows the cycle of $\mathrm{Cl}^{-} \rightarrow \mathrm{Cl}_{2} \rightarrow \mathrm{OCl}^{-} \rightarrow \mathrm{Cl}^{-}$in the role of electrons, the appropriate number of charge transfer only needs to be provided in theory, effective residual chlorine oxidants will be produced in the solution, and play the role of oxidation.

Cathode reaction: hydrogen will be dissolved out on the cathode and produce $\mathrm{OH}^{-}$ions.

$$
2 \mathrm{H}_{2} \mathrm{O}+2 e \rightarrow 2 \mathrm{OH}^{-}+\mathrm{H}_{2}
$$

Trace amounts of produced gas has the function of air floatation that oil and part of organics in the sewage can be suspended to the water surface in order to achieve the rapid purification of oily sewage.

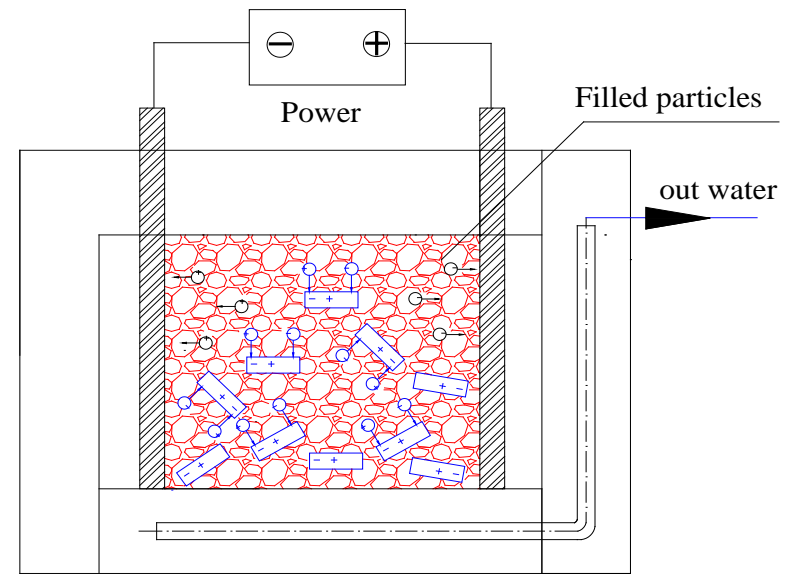

Figure 2. Principle of three-dimensional electrode reactor. 
Input a certain amount of sewage by $\mathrm{CH}$-II micro-continuous sewage treatment device to make particle electrodes completely immersed in sewage. Threedimensional electrocatalytic oxidation experiments are carried out under different reaction conditions, then take samples to analyze from the experimental procedure after electrolysis for a certain time, Use the WYK-60V DC power supply with automatic inverted pole control, and the steady-state output current can be adjusted according to the experimental requirement. The output current in the experiment can be adjusted and controlled at the range of $2-8 \mathrm{~A}$. The resident time of sewage is controlled by setting the displacement of the experimental pump to control the steady-state operation. The resident time of sewage in the experiment is controlled within $20-60 \mathrm{~min}$. The analysis of water quality index is carried out according to "Water and wastewater monitoring and analysis method" (end 4).

\section{Results and Discussions}

\subsection{The Effect of Electrode Filled Particles}

\section{1) Activated carbon}

Activated carbon is mostly used as electrode filled particles in three-dimensional electrode system. Good adsorption capacity of activated carbon greatly improves the utilization of anodic oxidation products, and then it can significantly reduce energy consumption, in addition, activated carbon has a strong ability to adapt the changes of water quality, water temperature and water volume, and saturated adsorbed activated carbon can be can be reused after regeneration. Pour the sewage into an electrolytic cell filled with activated carbon overnight before electrolysis to eliminate the effects of adsorption on COD.

Activated carbon filled electrode electrolysis is the combined process of adsorption and electrochemical, when reaching the equilibrium of the adsorption, desorption and electrolysis, the reaction removal rate will be stabilized. Use activated carbon as the main filler to design three-dimensional electrode, when the current is $5 \mathrm{~A}$, COD values at different electrolysis time are shown in Figure 3.

The experimental result shows that when the current is $5 \mathrm{~A}$ and the electrolysis

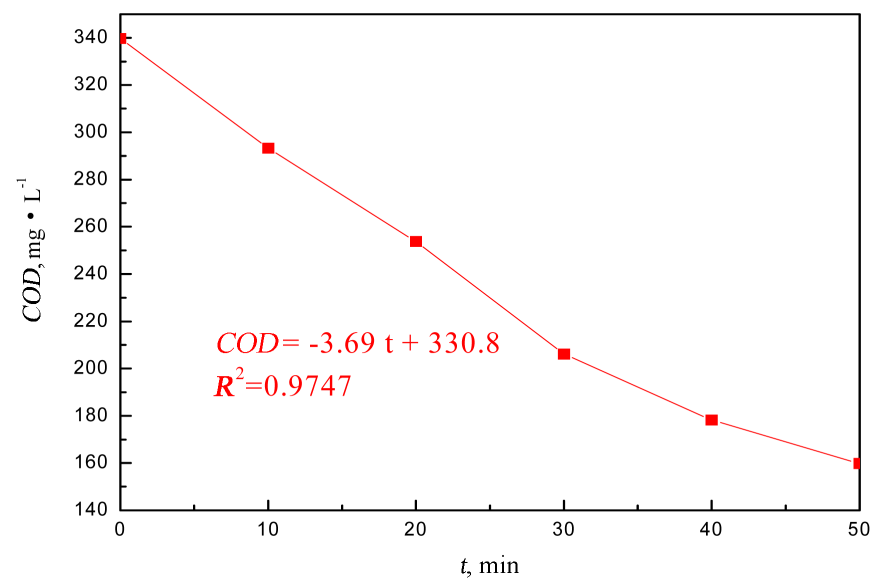

Figure 3. Changes of COD value at $5 \mathrm{~A}$. 
time is $50 \mathrm{~min}$, using activated carbon as electrode filled particles COD value is reduced from $340 \mathrm{mg} \cdot \mathrm{L}^{-1}$ to $159.8 \mathrm{mg} \cdot \mathrm{L}^{-1}$, and the COD removal rate is $53 \%$, and it still can not meet the index of less than $50 \mathrm{mg} \cdot \mathrm{L}^{-1}$. Current of the three-dimensional electrode can be divided into three parts: the reaction current, bypass current, short circuit current. To improve the efficiency of the electrode reaction, the effective reaction current on the electrode should be increased, and the bypass current and short circuit current should be minimized. Electrode filled particles mixed with a certain percentage of insulating particles in the three-dimensional electrode can improve the contact station of each other to make more particles isolated from each other, and then the short-circuit current between particles can be effectively reduced corresponding to increasing the Faraday current, and reaction efficiency is improved. Therefore, activated carbon mixed with a certain amount of other particles as electrode filled particles is designed to improve the efficiency of the reaction.

\section{2) Modified particles}

Use different particle filling methods [7] [11] [12] respectively as follows: 1) glass beads + activated carbon (The mass ratio is about 1:3), 2) glass beads + activated carbon + activated carbon coated by Cellulose acetate (Coating method: Weigh $10 \mathrm{~g}$ cellulose acetate, and make it dissolved in $1000 \mathrm{~g}$ glacial acetic acid, and $50 \%$ activated carbons are immersed in them, after 1 hour, take it out and make it dried out naturally in air. and then repeatedly wash it with tap water until the washing water is neutral, and then make it dried out naturally in air). 3) activated carbons + glass beads + quartz sands (The mass ratio is about 5:2:2), Take $200 \mathrm{~g}$ of quartz sand, glass beads and activated carbon, and mix evenly to fill in the two plates directly to form three-dimensional electrode. The electrochemical degradation experiments are carried out at the output current of $2 \mathrm{~A}$. The COD values at different resident times are shown in Figure 4.

Filling method 1: when using the filling method of glass beads + activated carbon with the current of $2 \mathrm{~A}$ and the electrolysis time of $50 \mathrm{~min}$, the COD value of the sewage is $106.9 \mathrm{mg} \cdot \mathrm{L}^{-1}$, and the removal rate of COD is up to $60.77 \%$.

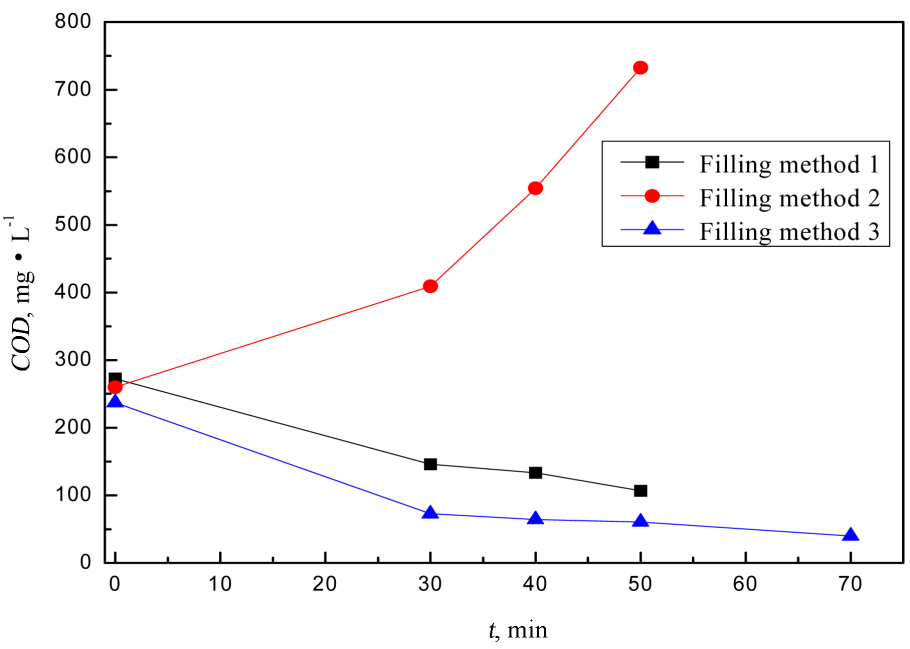

Figure 4. Changes of COD value under different particle filling methods. 
The removal rate of COD in the sewage is still lower than that of activated carbon alone in the case of reducing electrolysis current, indicating that the addition of glass beads can effectively improve the contact state between the activated carbon particles and improve the charge transfer in the reaction to improve reaction efficiency.

Filling method 2: The use of cellulose acetate on activated carbon coating to further improve the contact state between the activated carbon particles. Use the filling method of glass beads + activated carbon + activated carbon coated by Cellulose acetate to do three-dimensional electrolysis, and the COD value of sewage increases with the increasing of electrolysis time. The reason may be cellulose acetate itself is a polymer material, and membrane breaks down into decomposition in the process of electrolysis, so COD value does not fall but increase.

Filling method 3: Since the particle diameter of the glass beads is large, the effect is limited on improving the contact state between the activated carbon particles. Small particles of quartz sand (particle diameter of about $4 \mathrm{~mm}$ ) are used to further improve the contact between the activated carbon particles. When the electrolysis time is $50 \mathrm{~min}$ the removal rate of COD is above $74 \%$, which indicates that the addition of quartz sand particles further improves the electrolysis efficiency. The removal rate of the sewage is increased to $80 \%$ when the electrochemical treatment time is prolonged to $70 \mathrm{~min}$, and the COD value of the sewage is decreased from $237 \mathrm{mg} \cdot \mathrm{L}^{-1}$ to $50 \mathrm{mg} \cdot \mathrm{L}^{-1}$.

\subsection{The Effect of Electrode Material on Treatment}

The electrode material types are numerous in electrochemical treatment of COD in the sewage, here are many correlational researches: $\mathrm{IrO}_{2}, \mathrm{RuO}_{2}, \mathrm{PbO}_{2}, \mathrm{SnO}_{2}, \mathrm{Pt}$ electrode, BDD electrode and DSA electrode. Graphite electrode is low in mechanical strength and easy to be lossy, and carbon easily reacts with oxygen into $\mathrm{CO}$ and $\mathrm{CO}_{2}$ resulting in the corrosion of graphite electrode material. Lead ions of $\mathrm{PbO}_{2}$ electrode has secondary pollution. The service life of $\mathrm{SnO}_{2}$ electrode is not long. $\mathrm{Pt}, \mathrm{Au}, \mathrm{Ir}, \mathrm{Ru}$ and other metal electrodes are expensive and prone to be oxidized to form an oxide film covering the electrode surface leading to the inactivation of electrode. BDD electrode (boron-doped conductive diamond film electrode) [13] is of technical constraints, it is very difficult to produce large areas of BDD film and effectively realize the combination of film and substrate, the costs of industrial application can not be met. DSA electrode (dimensionally stable anodes) is a new type of anode material [14], whose base material is titanium and surface uses different oxide coatings by high temperature processing to improve its electrocatalytic activity, and the chemical composition of the oxide active coating can be adjusted according to the characteristics of the sewage, and its chemical composition is mainly transition metal oxides such as $\mathrm{RuO}_{2}, \mathrm{IrO}_{2}$, $\mathrm{SnO}_{2}, \mathrm{TiO}_{2}, \mathrm{PbO}_{2}, \mathrm{MnO}_{2}, \mathrm{Ta}_{2} \mathrm{O}_{5}$ and so on. Then add part of other transition metal oxides to form multiple composite active oxide coating (MMO, Mixed Metal Oxide). such as $\mathrm{RuO}_{2}-\mathrm{TiO}_{2}, \mathrm{RuO}_{2}-\mathrm{IrO}_{2}-\mathrm{TiO}_{2}, \mathrm{RuO}_{2}-\mathrm{IrO}_{2}-\mathrm{TiO}_{2}-\mathrm{SnO}_{2}$ 
coating system [8] [9]. The formed electrode has the advantages of high electrocatalytic activity, low working voltage, low energy consumption, strong corrosion resistance, simple production method and easy industrialization and low price [15] [16] [17] [18]. At the same time, the rare earth doped modification technology can enhance the electrode adsorption of the target pollutants, extend the life of the electrode [19] [20], improve catalytic efficiency and so on. In addition, Adding $\mathrm{SnO}_{2}$ into the oxide coating, $\mathrm{Sn}$ component can not only reduce the amount of $\mathbf{R u}$ but also improve the coating morphology and the role of electrocatalytic performance [21].

Based on optimized experimental study [22] [23], the mesh electrode plate is used in this study. The mesh plate makes the flow pattern of sewage in the reactor change from laminar flow to turbulent flow, and the thickness of the hydraulic boundary layer on the electrode surface is decreased, which enhances convection to improve the mass transfer performance of the reactor [24].

And the effective area of mesh electrode plate increases by $10 \%$ than the plate electrode. $3 \times 6$ mesh inert metal titanium is used as the base material in the experiment, and the surface is coated with a rare earth doped oxide active coating $\left(\mathrm{RuO}_{2}, \mathrm{IrO}_{2}, \mathrm{SnO}_{2}\right)$ treated at different ratio to form different DSA electrode plates $\mathrm{A} / \mathrm{C} / \mathrm{D} / \mathrm{F} /$, use particle filling methods 3 to form three-dimensional electrode reactor.

Their COD change trends are shown in Figure 5 at the sewage treated time by four kinds of electrode materials in the output current of $6 \mathrm{~A}$. The effect of four kinds of DSA electrode plates on the degradation of COD in sewage are different, and the effect of $\mathrm{F}$ electrode plate is the best, the COD of $\mathrm{F}$ electrode plate is degraded to $50 \mathrm{mg} \cdot \mathrm{L}^{-1}$ or less after treated about $25 \mathrm{~min}$. When increasing the electrolysis time, COD removal rate changes little, Extending electrochemical treated time for the degradation of residual pollutants is limited, At this time a large amount of electricity are consumed in the side reaction, in addition, substances adsorbed on the surface of activated carbon electrode material impede the electron transfer, so residual pollutants can not be further degraded.

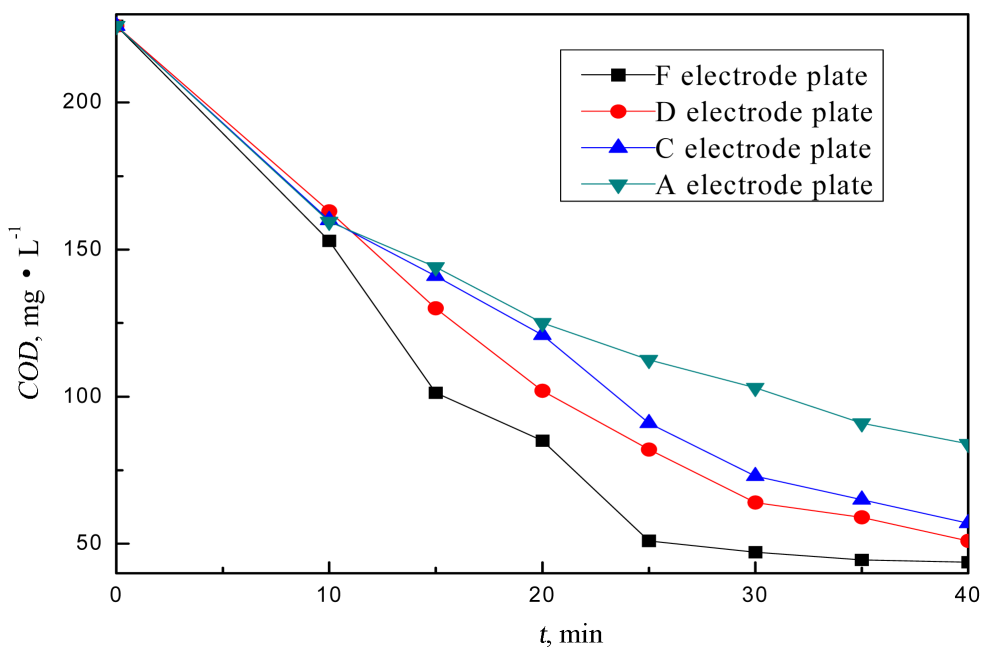

Figure 5. Changing trend of COD by different electrode materials at $6 \mathrm{~A}$. 


\subsection{The Effect of Electrolysis Current and Resident Time of Sewage}

The effective volume of the PFR electrochemical reactor filled with the threedimensional electrode material is about $3.9 \mathrm{~L}$, and the resident time of the sewage is controlled by adjusting the pump displacement. Set parameters to adjust the pump displacement as the timing quantitative mode in Table 2 before the dynamic electrolysis experiment.

Under the condition of voltage regulator and steady flow to control the output current of 2 - $8 \mathrm{~A}$, use the electrode plate mesh F-plate with the plate spacing of $60 \mathrm{~mm}$ as particle filling methods 3, and the dynamic electrolysis treatment of $3.9 \mathrm{~L}$ oilfield sewage is under the condition of different output currents, and the experimental results are shown in Figure 6. The effect of COD removal becomes better with the increasing of output current. The best effect of COD removal is at the output current of $6 \mathrm{~A}$ and $8 \mathrm{~A}$, taking into account the energy consumption, the experimental selection of the appropriate output current is $6 \mathrm{~A}$.

\subsection{SEM Analysis of the Electrode Pates}

SEM (scanning electron microscope) analysis is respectively performed on the positive and negative sides of the $\mathrm{F}$ electrode plate before and after the treatment of sewage (total $21.5 \mathrm{~h}$ ). Treatment process: spray gold under the protection treatment of nitrogen atmosphere, test condition: $10.0 \mathrm{kv}$ voltage. Observe whether there is dissolution and corrosion in the surface of respective electrodes after used, and the results are shown in Figure 7. The results of SEM $(10 \mu \mathrm{m})$

Table 2. Set the pump parameters.

\begin{tabular}{crrrrrrrrrrrr}
\hline Resident time/min & 10 & 15 & 20 & 25 & 30 & 35 & 40 & 45 & 50 & 55 & 60 \\
Flow rate/m·L $\cdot \mathrm{min}^{-1}$ & 390 & 260 & 195 & 156 & 130 & 111.43 & 97.5 & 86.67 & 78.00 & 70.91 & 65.00 \\
time/s & 300 & 300 & 300 & 300 & 300 & 300 & 300 & 300 & 300 & 300 & 300 \\
Quantitative/m.L & 1950 & 1300 & 975 & 780 & 650 & 557.15 & 487.5 & 433.33 & 390.00 & 354.55 & 325.00 \\
\hline
\end{tabular}

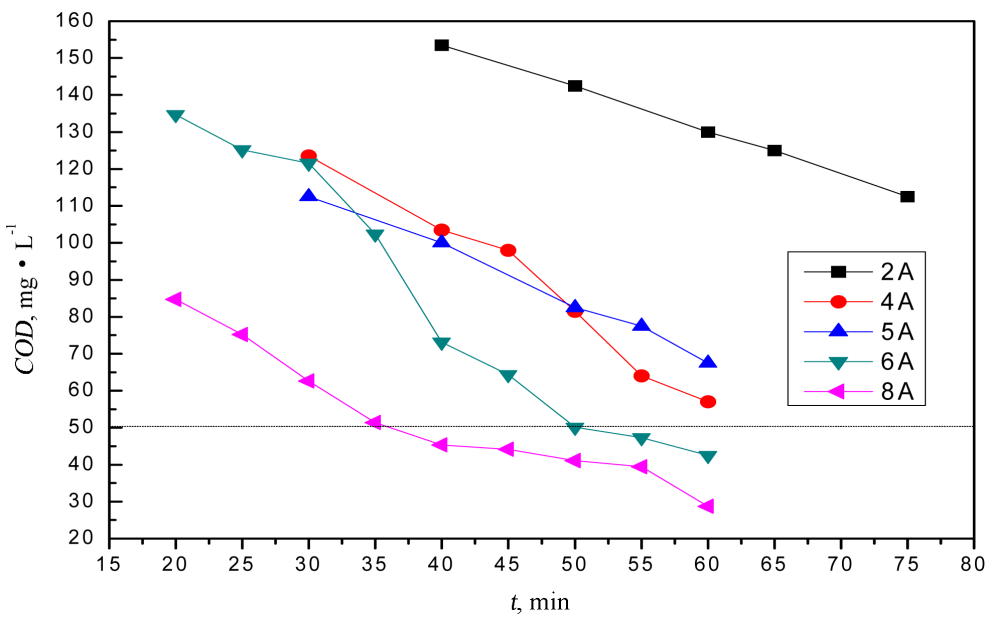

Figure 6. Changing trend of COD at different currents by F-plate. 
shows that the morphology of the used electrode plate samples are similar to that of the unused electrode plates, and there is no obvious dissolution and corrosion, indicating that the electrode material is stable.

\subsection{UV-Vis Absorption Spectra of Water Samples in the Process of Treatment}

Under the optimized experimental conditions: the output current of $6 \mathrm{~A}$, the inertia $\mathrm{F}$ mesh electrode plate, the electrode spacing of $6 \mathrm{~cm}$, the particle filling methods 3 , and the results of UV-Vis (ultraviolet-visible spectroscopy) absorption spectra of experimental series water samples in the process of the dynamic electrolytic treatment of $3.9 \mathrm{~L}$ oilfield sewage are shown in Figure 8 below.

There are three characteristic absorption bands of the polymer sewage in the range of $200-350 \mathrm{~nm}$ before treatment, respectively, the main absorption peak band $1(200-220 \mathrm{~nm})$, the shoulder absorption band $2(230-250 \mathrm{~nm})$, the main absorption peak band $3(280-310 \mathrm{~nm})$. The main absorption peak 1 may be caused by the conjugated structure of molecules and unsaturated ketones; The shoulder absorption band 2 may be caused by a benzene ring and its derivatives,
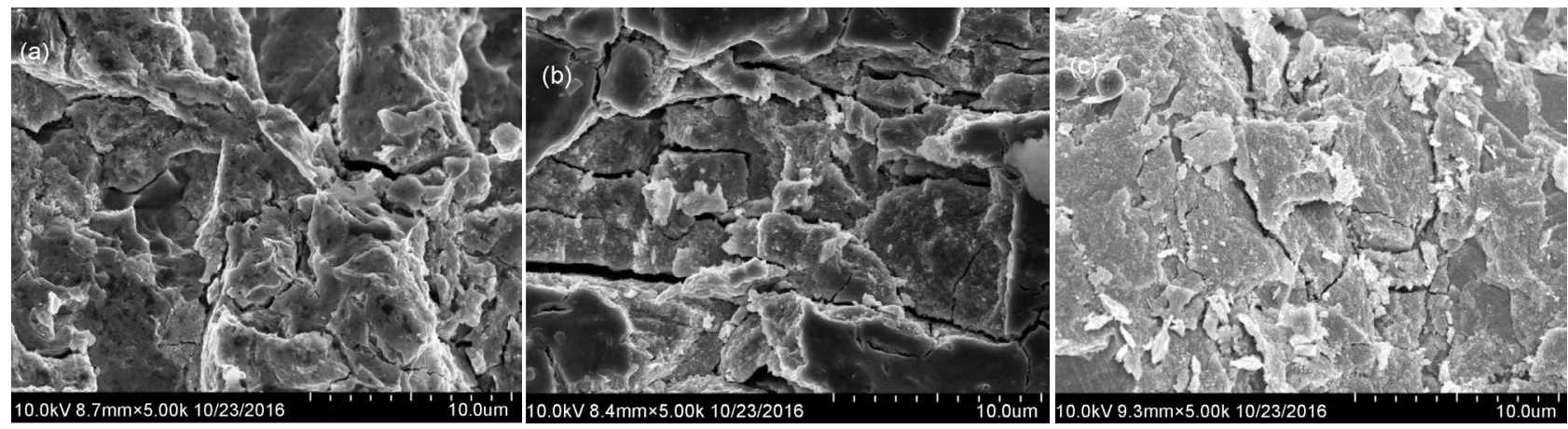

Figure 7. (a) SEM analysis of the unused electrode plate $(8.7 \times 5 \mathrm{~mm})$, (b) SEM analysis of the positive side of used electrode plate $(8.4 \times 5 \mathrm{~mm})$, (c) SEM analysis of the negative side of used electrode plate $(9.3 \times 5 \mathrm{~mm})$.

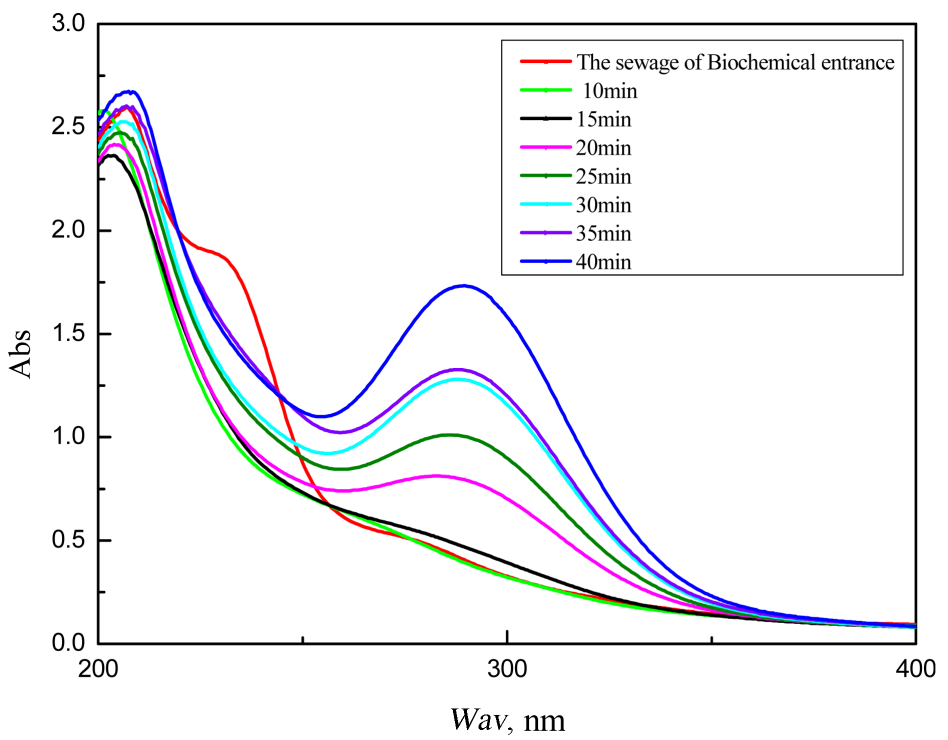

Figure 8. UV-Vis absorption spectra of experimental series water samples. 
they are mainly non-biodegradable substances; The main absorption band 3 may be a small molecule substances such as a carbonyl compound. The peak of the main absorption peak band 1 after electrolysis shows little change, indicating that the conjugated structure molecules and unsaturated ketones cannot be removed by electrolysis. The peak of the shoulder absorption band 2 after the electrolysis disappears, indicating that part of non-biodegradable substances in sewage are effectively removed and the biodegradability of the sewage after electrolysis is improved. As the electrolysis time increases, the peak value of the main absorption peak band 3 also increases, indicating that continuous small molecules such as carbonyl compounds are formed with the process of electrolysis, mainly because the benzene ring and its derivatives such macro molecular pollutants are continuously degraded into small molecules with the process of electrolysis.

\subsection{Analysis of Organic Pollutants in Sewage before and after Treatment}

The components and contents of organics in the extracted sewage before and after electrochemical treatment are analyzed by GC-MS. The analytical results are shown in Table 3 and Table 4 after spectral library search matching to determine the composition and content of organic pollutants in sewage before and after electrochemical treatment.

It can be seen from Table 3 that the contents of 10 kinds of aromatic oganics such as naphthalene, phenanthrene, thiophene, biphenyl, furan, flexor, pyrene, fluorene triaryl steroidal and other $\left(\mathrm{C}_{27}-\mathrm{C}_{29}\right)$ oganics in sewage are significantly reduced by electrochemical treatment, and the total concentration is decreased from $126.0 \mu \mathrm{g} \cdot \mathrm{L}^{-1}$ to $3.5523 \mu \mathrm{g} \cdot \mathrm{L}^{-1}$, the total removal rate is up to $97.181 \%$ after electrochemical treatment. Electrochemical removal efficiency of triaryl steroids and other $\left(\mathrm{C}_{27}-\mathrm{C}_{29}\right)$ organics are the best, and no triaryl steroids and other $\left(\mathrm{C}_{27}\right.$ $\mathrm{C}_{29}$ ) organics was detected in the electrochemically treated sewage. The aromatic hydrocarbon with lowest removal efficiency is biphenyl organics, and the removal rate is $84.35 \%$. Therefore, the electrochemical advanced treatment

Table 3. Content comparison of aromatic organic pollutants before and after treatment.

\begin{tabular}{cccc}
\hline organics & $\begin{array}{c}\text { Content before } \\
\text { Treatment, } \mu \mathrm{g} \cdot \mathrm{L}^{-1}\end{array}$ & $\begin{array}{c}\text { Content after } \\
\text { Treatment, } \mu \mathrm{g} \cdot \mathrm{L}^{-1}\end{array}$ & removal rate, \% \\
\hline Naphthalene organics & 18.29757 & 1.17654365 & 93.57 \\
Phenanthrene organics & 36.53337 & 0.7828346 & 97.86 \\
Thiophene organics & 5.425285 & 0.09409868 & 98.27 \\
Biphenyl organic & 2.168746 & 0.33940281 & 84.35 \\
Furan organics & 1.88387 & 0.218927 & 88.38 \\
Flexor organics & 11.41856 & 0.10654461 & 99.06 \\
Pyrene class organics & 4.27308 & 0.28938901 & 93.23 \\
Fluorene organics & 8.21153 & 0.54451162 & 93.37 \\
Triaryl steroidal organics & 14.90434 & 0 & 100 \\
Other $\left(\mathrm{C}_{27}-\mathrm{C}_{29}\right.$ ) oganics & 22.88323 & 0 & 100 \\
\hline
\end{tabular}


technology can significantly reduce the types and contents of aromatic organic pollutants in sewage.

It can be seen from Table 4 that the content and type of straight chain organics in the sewage are significantly increased after electrochemical treatment, the total concentration of straight chain organics is increased from $4.52 \mu \mathrm{g} \cdot \mathrm{L}^{-1}$ to $20.04 \mu \mathrm{g} \cdot \mathrm{L}^{-1}$, and the number of straight chain organics is increased by 9 from $\mathrm{C}_{14}-\mathrm{C}_{30}$ to $\mathrm{C}_{14}-\mathrm{C}_{39}$. A large amount of active free radicals may be produced during the electrochemical treatment process, resulting in the degradation of aromatic organics in the sewage. The content of generated straight chain hydrocarbons or molecular fragments increases with the decreasing in the types and content of aromatic organics in the aqueous solution. The concentration and types of straight chain organics in aqueous solution increase markedly, it shows an opposite trend with the decreasing in the types and content of aromatic pollutants in Table 3.

As can be seen from Table 5, COD value in sewage after electrochemical treatment is $48 \mathrm{mg} \cdot \mathrm{L}^{-1}$, the COD removal rate was $78.76 \%$ and reached the national and local control standard, and most of the aromatic organics are degraded.

\section{Conclusions}

1) Inert metal titanium is used as the base material with a rare earth doped oxide

Table 4. Content comparison of straight-chain organics before and after treatment $\left(\mu \mathrm{g} \cdot \mathrm{L}^{-1}\right)$.

\begin{tabular}{ccc|ccc}
\hline Organics & $\begin{array}{c}\text { Content before } \\
\text { treatment }\end{array}$ & $\begin{array}{c}\text { Content after } \\
\text { treatment }\end{array}$ & Organics & $\begin{array}{c}\text { Content before } \\
\text { treatment }\end{array}$ & $\begin{array}{c}\text { Content after } \\
\text { treatment }\end{array}$ \\
\hline $\mathrm{nC}_{14}$ & 0.107400 & 0.153109 & $\mathrm{nC}_{27}$ & 0.190169 & 1.766051 \\
$\mathrm{nC}_{15}$ & 0.162113 & 0.567409 & $\mathrm{nC}_{28}$ & 0.158458 & 1.370132 \\
$\mathrm{nC}_{16}$ & 0.159961 & 1.136367 & $\mathrm{nC}_{29}$ & 0.130488 & 1.124547 \\
$\mathrm{nC}_{17}$ & 0.308547 & 0.996596 & $\mathrm{nC}_{30}$ & 0.112438 & 0.845981 \\
$\mathrm{nC}_{18}$ & 0.225241 & 0.460175 & $\mathrm{nC}_{31}$ & 0.000000 & 0.652024 \\
$\mathrm{nC}_{19}$ & 0.317780 & 0.331687 & $\mathrm{nC}_{32}$ & 0.000000 & 0.462830 \\
$\mathrm{nC}_{20}$ & 0.252048 & 0.269583 & $\mathrm{nC}_{33}$ & 0.000000 & 0.297049 \\
$\mathrm{nC}_{21}$ & 0.309844 & 0.418337 & $\mathrm{nC}_{34}$ & 0.000000 & 0.266371 \\
$\mathrm{nC}_{22}$ & 0.338604 & 0.573476 & $\mathrm{nC}_{35}$ & 0.000000 & 0.257588 \\
$\mathrm{nC}_{23}$ & 0.342846 & 0.862588 & $\mathrm{nC}_{36}$ & 0.000000 & 0.320263 \\
$\mathrm{nC}_{24}$ & 0.842989 & 1.218675 & $\mathrm{nC}_{37}$ & 0.000000 & 0.144088 \\
$\mathrm{nC}_{25}$ & 0.316929 & 1.692987 & $\mathrm{nC}_{38}$ & 0.000000 & 0.143039 \\
$\mathrm{nC}_{26}$ & 0.245617 & 1.908709 & $\mathrm{nC}_{39}$ & 0.000000 & 1.766051 \\
\hline
\end{tabular}

Table 5. COD value in sewage before and after electrochemical treatment $\left(\mathrm{mg} \cdot \mathrm{L}^{-1}\right)$.

\begin{tabular}{cc}
\hline Measured COD value before treatment & Measured COD value after treatment \\
\hline 226 & 48 \\
\hline
\end{tabular}


active coating $\left(\mathrm{RuO}_{2}, \mathrm{IrO}_{2}, \mathrm{SnO}_{2}\right)$ to form mesh DSA electrode-F plate in the PFR three-dimensional electrode reactor filled with activated carbons, glass beads and quartz sands as the electrode particles (The mass ratio is correspondingly about 5:2:2).

2) The control parameters of the electrochemical reactor are as follows: the output current of $6 \mathrm{~A}$, the electrolysis time of $50 \mathrm{~min}$. The main pollutants in oilfield sewage can be degraded rapidly, and the COD is less than $50 \mathrm{mg} \cdot \mathrm{L}^{-1}$ after treatment.

3) The results of SEM show there is no obvious dissolution and corrosion, indicating that the electrode material is stable.

4) The results of UV-Vis absorption spectra show non-biodegradable pollutants in sewage are effectively removed.

5) 10 kinds of aromatic oganics such as naphthalene in sewage can be efficiently degraded by electrochemical treatment, and the total removal rate is up to $97.181 \%$. The content and type of straight chain organics in the sewage are significantly increased after electrochemical treatment, the total concentration of straight chain organics is increased from $4.52 \mu \mathrm{g} \cdot \mathrm{L}^{-1}$ to $20.04 \mu \mathrm{g} \cdot \mathrm{L}^{-1}$. COD in sewage mainly comes from all kinds of aromatic organics. After electrochemical treatment, the total COD in polymer flooding filtered sewage is only $48 \mathrm{mg} \cdot \mathrm{L}^{-1}$, which reaches the discharge control standard.

\section{Acknowledgements}

The authors are grateful for financial support from the National Science and Technology Major Project of China (No. 2016ZX05025-003) and Open Fund of State Key Laboratory of Offshore Oil Exploitation (Project No.

CCL2015RCPS0221RNN).

\section{References}

[1] Yang, M.Y., Jing, B., et al. (2016) Experimental Study on COD Composition and Electrochemical Degradation of Wastewater in Offshore Oilfields. Journal of Chinese Chemical Society, 63.

[2] Kai, H., Ishibashi, Y., Mori, T., et al. (2010) Decolorization and Estrogenic Activity of Colored Livestock Wastewater after Electrolysis Treatment. Journal of Material Cycles and Waste Management, 12, 128-135. https://doi.org/10.1007/s10163-009-0273-1

[3] Jiang, B., Zheng, J.T., Qiu, S., et al. (2014) Review on electrical Discharge Plasma Technology for Wastewater Remediation. Chemical Engineering Journal, 236, 348 368. https://doi.org/10.1016/j.cej.2013.09.090

[4] Zhao, X., Li, A.Z., Mao, R., Liu, H.J. and Qu, J.H. (2014) Electrochemical Removal of Haloacetic Acids in a Three-Dimensional Electrochemical Reactor with Pd-GAC Particles as Fixed Filler and Pd-Modified Carbon Paper as Cathode. Water Research, 51, 134-143. https://doi.org/10.1016/j.watres.2013.12.028

[5] Zhang, C., Jiang, Y.H., Li, Y.L., et al. (2013) Three-Dimensional Electrochemical Process for Wastewater Treatment: A General Review. Chemical Engineering Journal, 228, 455-467. https://doi.org/10.1016/j.cej.2013.05.033

[6] Rees, N.V., Zhou, Y.G. and Compton, R.G. (2012) Making Contact: Charge Trans- 
fer during Particle-Electrode Collisions. RSC Advances, 2, 379-384. https://doi.org/10.1039/C2RA01100J

[7] Cui, X.X. and Zhang, Y.G. (2013) Influence of Regularized Third Electrode on Three-Dimensional Electrode System. Environmental Science and Technology, 36, 115-119.

[8] Ban, F.C., Liu, J.T. and Chen, L. (2009) Effect of Packing Material on 3-D Electro-Fenton Treatment of Phenol Wastewater. Environmental Pollution and Control, 31, 24-26.

[9] Zhang, C.H., He, X.W. and Zhang, L.P. (2013) Research and Application of Electrochemical Technology in Water Treatment. China Environmental Press.

[10] Chen, W. and Mei, P. (2013) Electrochemical Techniques for Environmental Pollution Control. Beijing Petroleum Industry Press, Beijing.

[11] Zhang, B., Liu, J.J. and Che, Y.Q. (2005) Experimental Research on Treatment of Simulated Dyestuffs Wastewater with Three-Dimensional-Electrode Method. Journal of Jilin Institute of Chemical Technology, 22, 19-21.

[12] Qu, J.H. and Liu, H.J. (2007) Principle and Technology of Electrochemistry in Water Treatment. Science Press, Beijing.

[13] Li, X.M., Wang, J.D. and Chen, D.R. (2006) Experimental Investigation of Treatment of Wastewater Containing Chlorophenols Using Boron-Doped Diamond Film Electrodes. Journal of Tsinghua University (Science \& Technology), 46, 642-644.

[14] Trasatti, S. (2000) Electrocatalysis: Understanding the Success of DSA. Electrochimica Acta, 45, 2377-2385. https://doi.org/10.1016/S0013-4686(00)00338-8

[15] Zhang, Z.X. (2003) Techniques of Titanium Electrodes. 2nd Edition, Metallurgical Industry Press, Beijing.

[16] Da Silva, L.M., Fernandes, K.C., De Faria, L.A., et al. (2004) Electrochemical Impedance Spectroscopy Study during Accelerated Life Test of Conductive Oxides: $\mathrm{Ti} /(\mathrm{Ru}+\mathrm{Ti}+\mathrm{Ce}) \mathrm{O}_{2}$-System. Electrochimica Acta, 49, 4893-4906. https://doi.org/10.1016/j.electacta.2004.05.043

[17] Wang, X., Tang, D. and Zhou, J. (2007) Microstructure, Morphology and Electrochemical Property of $\mathrm{RuO}_{2} 70 \mathrm{SnO}_{2} 30 \mathrm{~mol} \%$ and $\mathrm{RuO}_{2} 30 \mathrm{SnO}_{2} 70 \mathrm{~mol} \%$ Coatings. Journal of Alloys and Compounds, 430, 60-66. https://doi.org/10.1016/j.jallcom.2006.04.058

[18] Villullas, H.M., Mattos-Costa, F.I. and Bulhoes, L.O.S. (2003) Oxygen Evolution on Platinum Modified $\mathrm{Ti} / \mathrm{RuO}_{2}$ Sol-Gel Films. Journal of Electroanalytical Chemistry, 545, 89-97. https://doi.org/10.1016/S0022-0728(03)00113-X

[19] Yang, W.H., Wang, H.H. and Fu, F. (2010) Preparation and Performance of Ti/ $\mathrm{Sb}-\mathrm{SnO}_{2} / \beta-\mathrm{PbO}_{2}$ Electrode Modified with Rare Earth. Rare Metal Materials and Engineering, 39, 1215-1218.

[20] Chu, Q.X., Liang, Z.H., Sun, Y.F., et al. (2009) Study of Electrochemical Properties of $\mathrm{Ti} / \mathrm{SnO}_{2}+\mathrm{Mn} \mathrm{Ox} / \mathrm{PbO}_{2}$ Electrode Doped with Rare Earth Y. Rare Metal Materials and Engineering, 38, 821-825.

[21] Han, C.H., Zhu, P.X., Guo, J.X., et al. (2013) Effects of Microsructures of Ti Anode Coating with Two Constituents $\left(\mathrm{Ruo}_{2}-\mathrm{TiO}_{2}\right)$ and Three Constituents $\left(\mathrm{RuO}_{2}-\mathrm{SnO}_{2}\right.$ $\mathrm{TiO}_{2}$ ) on the Electrochemical Properties. Acta Materiae Compositae Sinica, 30, 121 126.

[22] Zhu, M.J., Yao, J., Wang, W.B., et al. (2015) Using Response Surface Methodology to Evaluate Electrocoagulation in the Pretreatment of Produced Water from Polymer-Flooding Well of Dagang Oilfield with Bipolar Aluminum Electrodes. Desalination and Water Treatment, 3, 1-12. 
[23] Yan, F., Chen, W. and Danny, R. (2015) Electrochemical Stimulation of PAH Biodegradation in Sediment. Soil and Sediment Contamination: An International Journal, SCI. Soil and Sediment Contamination, 4, 143-156. https://doi.org/10.1080/15320383.2014.922932

[24] Su, J. (2011) Characterization of Fluid Dynamics and Mass Transfer in an Electrochemical Oxidation Reactor for Organic Pollutants. Jilin University, Jilin.

\section{Scientific Research Publishing}

Submit or recommend next manuscript to SCIRP and we will provide best service for you:

Accepting pre-submission inquiries through Email, Facebook, LinkedIn, Twitter, etc. A wide selection of journals (inclusive of 9 subjects, more than 200 journals)

Providing 24-hour high-quality service

User-friendly online submission system

Fair and swift peer-review system

Efficient typesetting and proofreading procedure

Display of the result of downloads and visits, as well as the number of cited articles Maximum dissemination of your research work

Submit your manuscript at: http://papersubmission.scirp.org/

Or contact ojogas@scirp.org 